\title{
Metabolic Effects of Very Low Calorie Weight Reduction Diets
}

\author{
Leonard J. Hoffer, Bruce R. Bistrian, Vernon R. Young, \\ George L. Blackburn, and Dwight E. Matthews \\ Human Nutrition Laboratory and the Clinical Research Center, \\ Massachusetts Institute of Technology, Cambridge, \\ Massachusetts 02139, the Cancer Research Institute, New \\ England Deaconess Hospital, Boston, Massachusetts 02215, and \\ the Metabolism Division, Washington University School of \\ Medicine, St. Louis, Missouri 63110
}

bstract. A randomized comparison trial of two very low calorie weight reduction diets was carried out for 5 or $8 \mathrm{wk}$ in 17 healthy obese women. One diet provided $1.5 \mathrm{~g}$ protein $/ \mathrm{kg}$ ideal body weight; the other provided $0.8 \mathrm{~g}$ protein $/ \mathrm{kg}$ ideal body weight plus $0.7 \mathrm{~g}$ carbohydrate $/ \mathrm{kg}$ ideal body weight. The diets were isocaloric (500 kcal). Amino acid metabolism was studied by means of tracer infusions of $\mathrm{L}-\left[1-{ }^{13} \mathrm{C}\right]$ leucine and $\mathrm{L}$ $\left[{ }^{15} \mathrm{~N}\right]$ alanine. After $3 \mathrm{wk}$ of adaptation to the diets, nitrogen balance was zero for the $1.5 \mathrm{~g}$ protein diet but -2 $\mathrm{g} \mathrm{N} / \mathrm{d}$ for the $0.8 \mathrm{~g}$ protein diet. Postabsorptive plasma leucine and alanine flux decreased from base line by an equal extent with both diets by $\sim 20$ and $40 \%$, respectively. It was concluded that protein intakes at the level of the recommended dietary allowance $(0.8 \mathrm{~g} / \mathrm{kg})$ are not compatible with nitrogen equilibrium when the energy intake is severely restricted, and that nitrogen balance is improved by increasing the protein intake above that level. Basal rates of whole body nitrogen turnover are relatively well maintained, compared with total fasting, at both protein intakes. However, turnover in the peripheral compartment, as evidenced by alanine flux, may be markedly diminished with either diet.

This is article $\mathbf{7 4 5}$ from the Cancer Research Institute of the New England Deaconess Hospital.

Dr. Hoffer is a Fellow of the Medical Research Council of Canada. Address all reprint requests to Dr. Bistrian, Cancer Research Institute, Boston, MA 02215

Received for publication 19 May 1983 and in revised form $18 \mathrm{No}$ vember 1983.

J. Clin. Invest.

(C) The American Society for Clinical Investigation, Inc.

0021-9738/84/03/0750/09 \$1.00

Volume 73, March 1984, 750-758

\section{Introduction}

Very low calorie diets providing $200-600 \mathrm{kcal} / \mathrm{d}$ are widely used in weight reduction therapy. The safety and optimal composition of these diets remains an area of concern in view of the hazards of prolonged total fasting and of some low-nutritive value liquid protein products used for weight reduction $(1,2)$. An area of particular concern is the protein nutritional status of individuals following very low calorie diets for prolonged periods of time. Such diets in current use vary considerably in their daily protein allotment; they frequently provide levels at or below the recommended dietary allowance (RDA) ${ }^{1}(3)$, despite evidence that caloric restriction increases the protein requirement for zero nitrogen balance $(3,4)$. Nitrogen balance studies have been carried out with obese individuals following differently formulated, very low calorie diets providing different amounts of protein, but with varying results. In one controlled study, obese individuals followed sequential $400 \mathrm{kcal}$ diets providing either $100 \mathrm{~g}$ protein alone or $50 \mathrm{~g}$ protein and $50 \mathrm{~g}$ carbohydrate. Nitrogen balance was negative during the third week with either diet (5). Other investigators, however, have reported nitrogen equilibrium in obese subjects on very low calorie diets providing as little as $31 \mathrm{~g}$ protein/d (6). Uncontrolled studies carried out by our group suggest that protein intakes at the RDA level $(0.8$ $\mathrm{g} / \mathrm{kg}$ ) do not permit nitrogen equilibrium in the setting of severe calorie restriction, but increases to $1.5 \mathrm{~g} / \mathrm{kg}$, based on the ideal body weight (IBW), result in mean nitrogen equilibrium in groups of moderately obese women $(7,8)$. The discrepant results from different laboratories might be explained in part by known difficulties with the nitrogen balance technique and its interpretation $(9,10)$. To test the consistency of our earlier results, we have carried out a randomized comparison trial of two isocaloric, very low calorie weight reduction diets at different protein levels, with the goal of studying a large number of individuals over a prolonged period.

1. Abbreviations used in this paper: IBW, ideal body weight; RDA, recommended dietary allowance. 
In addition to nitrogen balance, plasma amino acid turnover was measured in subjects on the two diets. It is now recognized that a major proportion of body protein undergoes continuous synthesis and breakdown, with the result that dietary intake accounts for only about one-third of the daily turnover of the free amino acid pools of the body (11). Studies using a variety of techniques indicate that body protein turnover diminishes substantially in protein calorie malnutrition (12), during intakes of protein-deficient diets (13) and during prolonged total fasting $(14,15,16)$. This response, presumably, is part of a mechanism to conserve existing body protein stores. In clearance studies using nontracer infusions of leucine, Sherwin (16) determined in humans that the plasma delivery rate of leucine diminishes $65 \%$ from normal postabsorptive values after $4 \mathrm{wk}$ of a total fast. In that study, the plasma appearance of endogenously produced leucine was estimated from changes in plasma isoleucine levels. This method might not provide reliable estimates for absolute leucine turnover during fasting, but could still be useful in making comparisons with a base-line condition. Indeed, similar percentage declines have been obtained upon direct measurement of the tissue release of essential amino acids in prolonged fasting man (14). Alanine release from peripheral tissues diminishes to a similar extent, reflecting the diminution of net protein breakdown in the periphery with consequently less nitrogen transfer to the liver for urea synthesis (17). Consistent with these direct observations, plasma alanine appearance, as measured with the tracer $\mathrm{L}-\left[\mathrm{U}-{ }^{14} \mathrm{C}\right]$ alanine, has been reported to diminish $65 \%$ from postabsorptive values during prolonged total fasting (18).

The influence of very low calorie diets on body protein turnover is incompletely explored. Knowledge of important effects would be valuable because a diet providing a favorable overall nitrogen balance might still be undesirable if this was obtained only by means of a major diminution in body protein turnover rates (19). In the present study, plasma leucine turnover was measured by using the $4-\mathrm{h}$, tracer $\mathrm{L}-\left[1-{ }^{13} \mathrm{C}\right]$ leucine continuous infusion technique in the postabsorptive state (20). This determination of basal turnover permits a comparison between the two diets and with the literature on total fasting. Additionally, plasma alanine turnover was measured by using tracer infusions of $\mathrm{L}-\left[{ }^{15} \mathrm{~N}\right]$ alanine. Under the study conditions, plasma alanine appearance may provide an indication of the turnover of proteins in the peripheral tissues $(17,21)$, and thereby provide information complementary to the estimate of protein turnover in the body as a whole derived from the leucine flux measurement.

\section{Methods}

Subjects and procedures. 17 moderately obese young women in good health and receiving no medication were admitted to the Clinical Research Center of the Massachusetts Institute of Technology. Moderate obesity was defined as body weight between 130 and $200 \%$ IBW determined from tabulated average acceptable medium frame weight for height (22). All subjects underwent a complete medical history, physical examination, electrocardiogram, chest $\mathrm{x}$-ray, urinalysis, and clinical chemistries (electrolytes, blood-urea nitrogen, creatinine, glucose, uric acid, magnesium, calcium, phosphate, total bilirubin, glutamate-pyruvate transaminase, alkaline phosphatase, cholesterol, triglycerides, thyroxin, ferritin, hemoglobin, differential leukocyte count, and platelets). The subjects were inpatients allowed to continue their daytime activities. Vital signs were determined twice daily, and body weight determined at the same time each morning in bedclothes immediately after voiding. The diets were prepared as three equal meals taken in the Clinical Research Center dining room, except the noon meal which was usually taken at the workplace. For the first $\mathbf{4 d}$, each subject received a formula diet providing maintenance energy and $1.5 \mathrm{~g}$ protein $/ \mathrm{kg}$ IBW (Ensure, Ross Laboratories, Columbus, $\mathrm{OH}$, supplemented with egg albumin). On the fifth day, subjects were allocated to one of the two experimental diets according to a predetermined random code known only by the dietician. One diet consisted only of lean ground beef providing $1.5 \mathrm{~g}$ protein/ $\mathrm{kg}$ IBW (" 1.5 diet"); the other provided $0.8 \mathrm{~g}$ protein $/ \mathrm{kg}$ IBW plus $0.7 \mathrm{~g}$ carbohydrate (Polycose Glucose Polymer, Ross Laboratories, Inc.)/kg IBW plus a small amount of butter to make the diets equivalent in calories and fat ("0.8 diet"). The beef was purchased in large lots and analyzed for nitrogen content by the Kjeldahl method (23). At the end of the study, the energy content of the lots was determined by oxygen bomb calorimetry (Parr Adiabatic Calorimeter 1241, Parr Instrument Co., Moline, IL) to confirm that the diets were isocaloric. Supplemented daily to the 1.5 diet were potassium, 25 meq; "One-a-Day plus Minerals" (Miles Laboratories, Inc., Elkhart, IN); magnesium, $300 \mathrm{mg}$; calcium, $800 \mathrm{mg}$; iron, $38 \mathrm{mg}$ (ferrous gluconate); and sodium chloride, $5 \mathrm{~g}$ minimum. Supplemented daily to the 0.8 diet were potassium, $37.5 \mathrm{meq}$; "Onea-Day plus Minerals"; magnesium, $300 \mathrm{mg}$; calcium, $800 \mathrm{mg}$; iron, 38 $\mathrm{mg}$; phosphate, $300 \mathrm{mg}$; and sodium chloride, $5 \mathrm{~g}$ minimum. All subjects were encouraged to liberally drink noncaloric fluids. No more than one cup of coffee or tea was taken each day, and no subject smoked. Complete urine and fecal collections were kept. $15 \mathrm{ml}$ of $30 \% \mathrm{HCl}$ was added as preservative to each 2-liter urine collection bottle; the bottles were kept refrigerated over the collection period, and then aliquots were removed and frozen until analysis. Fecal collections were pooled weekly by means of stool markers. Nitrogen balance was determined from the intake and urine and fecal output with assumed unmeasured nitrogen losses of 5 $\mathrm{mg} / \mathrm{kg}$ (24). The study diets were given for $5 \mathrm{wk}$; then, a subset of four subjects on each diet continued for $3 \mathrm{wk}$ more to make $8 \mathrm{wk}$ of continuous dieting.

Dietary compliance was monitored by daily interview, by daily urinary urea, sodium, and potassium determinations, by twice-daily urinary acetoacetate (Ames Acetest, Miles Laboratories, Inc.) and breath acetone by using a gas chromatography apparatus (Caldetect Diet Monitor, $\mathrm{Cal}$ detect, Inc., Richmond, CA), and by weekly determinations of whole blood glucose and $\beta$-hydroxybutyrate. Patients were offered a year's free weekly dietary monitoring and counseling at the end of the inpatient phase as both an incentive and to repay them for their participation in the study. Each subject was informed of the nature and risks involved in the study, and consent was obtained for the study protocol and approved by the Massachusetts Institute of Technology Committee on the Use of Humans as Experimental Subjects and the Executive Committee of the Clinical Research Center.

Tracer studies. Fasting (postabsorptive) plasma leucine and alanine flux were determined the morning of the third or fourth day on the control diet, after $21 \mathrm{~d}$ of dieting, and (in some cases) after $8 \mathrm{wk}$ of dieting by means of continuous primed tracer isotope infusions. Short intravenous catheters were placed aseptically in superficial hand veins for arterialized blood sampling by using a thermostatically controlled 
hand-warming box (25). The isotope administration catheter was placed in an antecubital vein and the arm kept immobile. At the beginning of each study, blood and expired air samples were collected to determine base-line enrichments of the metabolites of interest prior to tracer administration. Blood was drawn into heparinized tubes kept on ice and the plasma removed and frozen until analysis. Expired air was collected in anesthesia bags with a Rudolph valve and mouth piece; it was immediately bubbled through $0.1 \mathrm{~N} \mathrm{NaOH}$ and the solution was collected into tightly closing vials until analysis for ${ }^{13} \mathrm{CO}_{2}$ enrichment by isotope ratio mass spectrometry. Plasma samples were taken every $15 \mathrm{~min}$ and air samples every 12 min during the fourth infusion hour. $\mathrm{CO}_{2}$ production rate was determined by using a gasometer connected by tubing to a Rudolph valve and mouthpiece with noseclips. After determination of the minute ventilation, trapped air was passed through a Beckman LB2 Medical Gas Analyzer and an E-2 Oxygen Analyzer (Beckman Instruments, Inc., Fullerton, CA); 6-8 5-min determinations were usually made. The leucine tracer $\left(90 \% \mathrm{~L}-\left[1-{ }^{13} \mathrm{C}\right]\right.$ leucine; Kor Isotopes, Inc., Cambridge, MA) was infused at $0.075 \mu \mathrm{mol} / \mathrm{kg} / \mathrm{min}$ with a priming dose-to-infusion ratio of 60 per minute. The alanine tracer $(99 \% \mathrm{~L}-$ $\left[{ }^{15} \mathrm{~N}\right]$ alanine, Kor Isotopes, Inc.) was infused at $0.13 \mu \mathrm{mol} / \mathrm{kg} / \mathrm{min}$; no priming dose was administered. The bicarbonate pool was enriched at the beginning of the infusion by an injection of $\left[{ }^{13} \mathrm{C}^{\mathrm{NaHCO}}{ }_{3}, 0.9 \mu \mathrm{mol} /\right.$ $\mathrm{kg}$ (26). For dosage calculations, the weight of all subjects was taken as $52 \mathrm{~kg}$. Tracers were verified sterile and pyrogen-free, diluted in sterile saline, and infused by calibrated syringe pump at $0.174 \mathrm{ml} / \mathrm{min}$.

Analytical methods. Clinical chemistries were determined by using routine semi-automated methods. Urine and fecal nitrogen were determined by the Kjeldahl method (23). Whole blood glucose and $\beta$-hydroxybutyrate were determined enzymatically (27), plasma free fatty acids by a radiochemical method (28), amino acids with a Dionex D400 amino acid analyzer (Dionex Corp., Sunnyvale, CA), and serum insulin by radioimmunoassay (29). The ${ }^{13} \mathrm{C}$-enrichment of expired $\mathrm{CO}_{2}$ was measured with a dual collector isotope ratio mass spectrometer (Model 3-60 RMS, Nuclide Corp., State College, PA). Plasma isotopic leucine and alanine enrichments were determined by selected ion-monitoring, chemical ionization gas chromatography-mass spectrometry on a Finnigan 3300 dual EI/CI quadrupole mass spectrometer (Finnigan MAT, San Jose, CA) under computer control, following isolation of the free amino acids by using an ion exchange column and the preparation of their $N$-acetyl, $n$-propyl derivatives (30). Plasma $\alpha$-ketoisocaproate enrichment was determined by using the same method, after isolation of the ketoacid and its reaction with $o$-phenylenediamine, permitting the formation of the $a$-trimethylsilylquinoxalinol derivative (31).

Calculations and statistical methods. Plasma leucine and alanine flux were calculated from the measured dilution of tracer in the plasma amino acid pool once isotopic steady state was reached, according to the equation: flux $=i\left(\mathrm{E}_{i} / \mathrm{E}_{p}-1\right)$, where $i$ is the tracer infusion rate, $E_{i}$ is the enrichment of the administered isotope, and $E_{p}$ is the enrichment in plasma at isotopic steady state. The rate of leucine oxidation was calculated from the measured ${ }^{13} \mathrm{CO}_{2}$-enrichment of expired air at isotopic steady state, according to the equation: oxidation rate $=\mathrm{E}_{\mathrm{CO}_{2}} \cdot \mathrm{V}_{\mathrm{CO}_{2}} /$ $\mathrm{E}_{p} \cdot(0.8)$ where $\mathrm{E}_{\mathrm{CO}_{2}}$ is the ${ }^{13} \mathrm{CO}_{2}$-enrichment in expired air, $\mathrm{V}_{\mathrm{CO}_{2}}$ is the rate of $\mathrm{CO}_{2}$ production, and 0.8 is an empirical correction factor that accounts for the fraction of ${ }^{13} \mathrm{CO}_{2}$ formed on oxidation of $\left[1-{ }^{13} \mathrm{C}\right]$ leucine but not released from the body bicarbonate pool into expired air (32). It has been reported that this factor is unaltered under conditions of prolonged fasting (33). The attainment of isotopic steady state was confirmed by inspection of the serial plasma and air enrichments during the final hour of the infusion. The precision of this technique has been described in detail (20). Statistical comparisons were made using $t$ test or the paired $t$ test when applicable.

\section{Results}

The subjects' characteristics and the diet compositions are shown in Table I. The diets were well tolerated by all the subjects and there were no untoward medical events, significant postural hypotension, nor abnormalities in the clinical chemistries during the study. Mean rates of weight loss were similar for both diet groups at all times; after $2 \mathrm{wk}$, the mean rate was $0.2 \mathrm{~kg} / \mathrm{d}$ (Fig. 1).

Serum uric acid rose equally for both diets from values of $\sim 5.1 \mathrm{mg} / \mathrm{dl}$ to $8.7 \pm 1.4$ and $7.6 \pm 1.5($ mean $\pm \mathrm{SD})$ at 3 wk for the 1.5 and 0.8 diets, respectively. By $5 \mathrm{wk}$, values had fallen to 6.6 and 5.8 for the two diets. The differences in means between the diets were not statistically significant. Serum cholesterol fell significantly from control values of $\sim 185 \mathrm{mg} / \mathrm{dl}$ to $\sim 150 \mathrm{mg} /$ $\mathrm{dl}$, while triglycerides remained at control values of $\sim 90 \mathrm{mg} /$ $\mathrm{dl}$ with both diets. Circulating glucose, alanine, and insulin decreased with both diets while leucine, free fatty acids, and $\beta$-hydroxybutyrate increased, as shown at $3 \mathrm{wk}$ of dieting in Table II. The decrease in alanine and increase in leucine plasma concentrations were significantly greater with the 1.5 diet. Daily nitrogen balance, averaged over each week for all subjects, is shown in Table III. Although their results are valid, three subjects

\section{Table I. Patient and Diet Characteristics}

\begin{tabular}{|c|c|c|}
\hline \multirow[b]{2}{*}{ Comparison* } & \multicolumn{2}{|c|}{ Dietary group } \\
\hline & 1.5 diet & 0.8 diet \\
\hline \multicolumn{3}{|l|}{ Number of subjects: } \\
\hline Studied for $5 \mathrm{wk}$ & 9 & 8 \\
\hline Studied for $8 \mathrm{wk}$ & 4 & 4 \\
\hline Age $(y r)$ & $25 \pm 4$ & $26 \pm 4$ \\
\hline Weight $(k g)$ & $84 \pm 10$ & $87 \pm 9$ \\
\hline$\%$ IBW & $148 \pm 18$ & $159 \pm 18$ \\
\hline Resting $\mathrm{O}_{2}$ consumption $(\mathrm{ml} / \mathrm{min}$ ) & $208 \pm 9$ & $198 \pm 21$ \\
\hline \multicolumn{3}{|l|}{ Control period diet } \\
\hline Protein $(g)$ & $86 \pm 7$ & $82 \pm 3$ \\
\hline Carbohydrate $(g)$ & $268 \pm 45$ & $250 \pm 14$ \\
\hline kcal & $2034 \pm 307$ & $1888 \pm 68$ \\
\hline \multicolumn{3}{|l|}{ Study diet } \\
\hline Protein $(g)$ & $85 \pm 6$ & $44 \pm 2$ \\
\hline Carbohydrate $(g)$ & 0 & $38 \pm 2$ \\
\hline Fat $(g)$ & $23 \pm 7$ & $18 \pm 4$ \\
\hline kcal & $559 \pm 79$ & $501 \pm 39$ \\
\hline
\end{tabular}

* Values expressed as mean $\pm \mathrm{SD}$. 


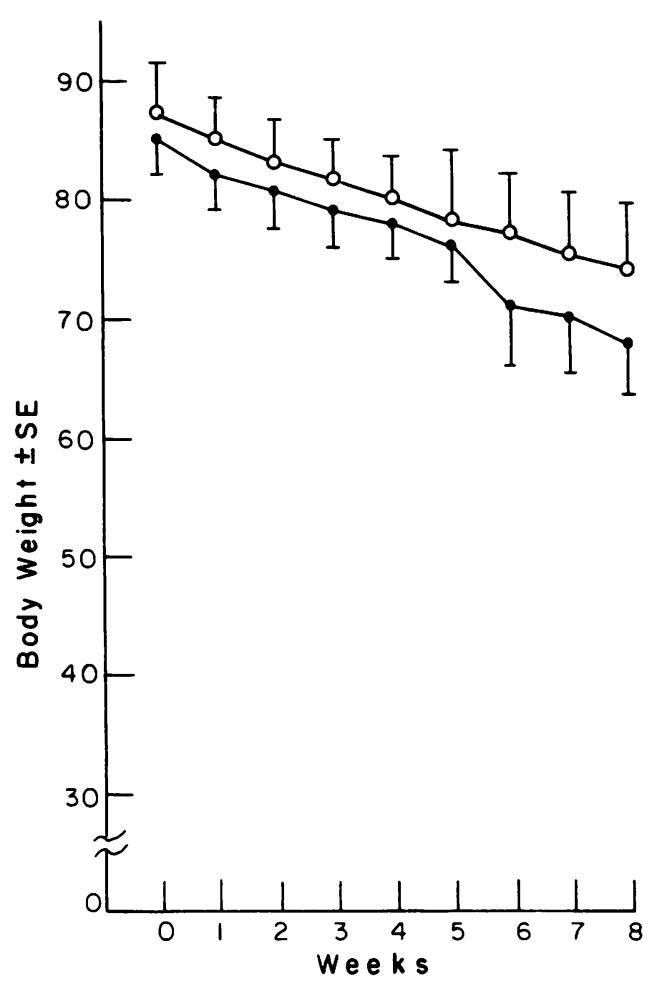

Figure 1. Average weight $(\mathbf{k g})$ at the end of different weeks for two weight reduction diets. Open circles indicate values for the 1.5 diet, closed circles for the 0.8 diet. 15 subjects were included in the determination weeks $0-5 ; 8$ were included in the determination weeks 6-8.

did not complete the full period of the protocol. Because it might bias serial comparisons, their results are not included in calculations of the group means, but instead are displayed in parentheses in Table III. Inclusion of their results, however, does not alter the conclusions derived from the rest of the data. Average fecal nitrogen $(0.6 \mathrm{~g} / \mathrm{d})$ did not differ between the diets. Overall nitrogen equilibrium existed during the control period. During the first study week, the balance fell to -4 or $-5 \mathrm{~g}$ $\mathrm{N} / \mathrm{d}$ with both diets, but returned to near equilibrium with the 1.5 diet in the second week while remaining significantly negative $(-2 \mathrm{~g} / \mathrm{d})$ with the 0.8 diet. The differences between the means were significant $(P<0.05)$ at weeks $2,3,4,6$, and 8 (Fig. 2). The subset of subjects who dieted for $3 \mathrm{wk}$ were not different in their response from the 5-wk subjects on the same diet.

Postabsorptive plasma leucine flux and oxidation rate during the control period and after 3 and 8 wk of dieting, expressed as micromoles per minute, are shown in Table IV. Expressing the results per $\mathrm{kg}$ actual body weight or IBW does not alter the conclusions (Table IV). After 3 wk of adaptation to the diets, leucine flux had fallen by 15 and $20 \%$ ( 1.5 and 0.8 diets); both changes are statistically significant $(P<0.05)$. There was no significant change in oxidation with the 1.5 diet, but a $30 \%$ decrease with the 0.8 diet $(P<0.05)$. The six repeat studies carried out at $8 \mathrm{wk}$ demonstrate little further change in leucine flux, being within $5 \%$ of the 3-wk determinations with one exception (C.M.). For the two groups combined, there is a linear relationship between fasting leucine oxidation and urinary total nitrogen during the third week (Fig. 3). This relationship suggests that leucine oxidation, at least in the fasting state, reflects whole body amino acid oxidation. This is supported by the additional observation that nitrogen balance during the third week negatively correlated with leucine oxidation for each dietary group separately $(r=-0.80$ for the 1.5 diet, $r=-0.85$ for the 0.8 diet, both $P<0: 02$ ).

It was considered possible that changes in plasma leucine flux might not accurately reflect body leucine metabolism during severe energy restriction. Plasma and intracellular free amino acid tracer dilutions are unequal, intracellular leucine enrichment being $\sim 80 \%$ of that in plasma at isotopic equilibrium (31). If slowing of intracellular amino acid turnover allowed a closer approximation of intracellular and plasma enrichments, the full extent of a decline in the turnover might not be expressed in the flux calculated from plasma leucine enrichments. To investigate this possibility, plasma ${ }^{13} \mathrm{C}$-enrichment of $\alpha$-ketoisocaproate was determined for the three turnover studies of three subjects (C.M., L.J., S.S.). As $\alpha$-ketoisocaproate is derived via intracellular leucine transamination, plasma enrichment of the ketoacid reflects the intracellular enrichment of leucine (31). Plasma $\alpha$-ketoisocaproate enrichment was $79.6 \pm 5.1 \%$, $79.3 \pm 0.9 \%$, and $82.1 \pm 3.3 \%$ (mean \pm SD) of plasma leucine enrichment after 0,3 , and 8 wk of dieting. This rules out the possibility that adaptation to the experimental diets brought

Table II. Fasting Circulating Metabolite and Insulin Concentrations

\begin{tabular}{lccc}
\hline Measured entity* & Diet & $\begin{array}{l}\text { Control } \\
\text { period diet }\end{array}$ & $\begin{array}{l}\text { Third week of } \\
\text { dieting }\end{array}$ \\
\hline $\begin{array}{l}\text { Whole Blood Glucose } \\
(m g / d l)\end{array}$ & 1.5 & $79 \pm 17$ & $59 \pm 15 \ddagger$ \\
$\quad \begin{array}{l}\text { Whole blood } \beta \text { - } \\
\text { hydroxybutyrate }\end{array}$ & 1.5 & $0.13 \pm 0.10$ & $2.77 \pm 0.61 \ddagger \S$ \\
$\quad(m M)$ & 0.8 & $0.12 \pm 0.14$ & $1.90 \pm 0.46 \ddagger \S$ \\
Plasma free fatty acids & 1.5 & $0.68 \pm 0.16$ & $0.98 \pm 0.29 \ddagger$ \\
$\quad(m e q /$ liter $)$ & 0.8 & $0.71 \pm 0.14$ & $0.96 \pm 0.24 \ddagger$ \\
Plasma leucine $(\mu M)$ & 1.5 & $126 \pm 15$ & $168 \pm 27 \ddagger \S$ \\
& 0.8 & $124 \pm 12$ & $134 \pm 18 \S$ \\
Plasma alanine $(\mu M)$ & 1.5 & $273 \pm 79$ & $154 \pm 41 \ddagger \S$ \\
& 0.8 & $291 \pm 81$ & $206 \pm 45 \ddagger \S$ \\
Serum insulin & 1.5 & $34.0 \pm 24.2$ & $11.7 \pm 5.3 \ddagger$ \\
$\quad(\mu \mathrm{U} / \mathrm{ml})$ & 0.8 & $35.7 \pm 31.1$ & $18.3 \pm 15.4 \ddagger$ \\
\hline
\end{tabular}

* Values expressed as mean \pm SD.

¥ Significantly different from control period value, $P<0.05$. $\S$ Significantly different from the other diet, $P<0.05$. 
Table III. Weekly Average Nitrogen Balance ( $\mathrm{g} N / \mathrm{d})$

\begin{tabular}{|c|c|c|c|c|c|c|c|c|c|c|}
\hline \multirow[b]{2}{*}{ Subject } & \multicolumn{10}{|c|}{ 1.5 Diet } \\
\hline & K.B. & J.B. & L.C. & H.H. & B.M. & C.M. & J.R. & D.S. & K.W. & Mean $\pm S D^{*}$ \\
\hline \multicolumn{11}{|l|}{$\begin{array}{l}\text { Week } \\
\text { control }\end{array}$} \\
\hline period & $-0.33 \pm 0.37$ & $+1.62 \pm 0.52$ & $+1.21 \pm 1.17$ & $-1.01 \pm 1.43$ & $-0.32 \pm 0.91$ & $+0.54 \pm 0.61$ & $(-0.74 \pm 1.35)$ & $+1.79 \pm 3.65$ & $+0.49 \pm 1.18$ & $+0.50 \pm 1.00$ \\
\hline 1 & $-4.90 \pm 1.13$ & $-5.20 \pm 1.87$ & $-4.19 \pm 1.78$ & $-3.46 \pm 2.00$ & $-2.75 \pm 1.80$ & $-2.13 \pm 1.17$ & $(-3.52 \pm 2.78)$ & $-5.06 \pm 2.59$ & $-4.41 \pm 1.52$ & $-4.01 \pm 1.13$ \\
\hline 2 & $-3.45 \pm 1.05$ & $-1.10 \pm 1.48$ & $-2.01 \pm 1.29$ & $-2.49 \pm 1.96$ & $-1.31 \pm 0.78$ & $+1.32 \pm 0.95$ & $(-0.18 \pm 1.37)$ & $-3.04 \pm 0.73$ & $+0.88 \pm 1.88$ & $-0.54 \pm 2.22$ \\
\hline 3 & $-1.62 \pm 0.84$ & $-1.52 \pm 0.67$ & $-1.81 \pm 2.52$ & $-1.23 \pm 1.23$ & $-0.43 \pm 0.40$ & $-0.73 \pm 0.30$ & $(+0.81 \pm 0.80)$ & $+1.01 \pm 0.50$ & $+2.39 \pm 1.28$ & $-0.49 \pm 1.47$ \\
\hline 4 & $-1.90 \pm 0.69$ & $-1.01 \pm 0.58$ & $-0.75 \pm 0.64$ & $-0.28 \pm 1.46$ & $-0.64 \pm 0.45$ & $-0.80 \pm 1.64$ & - & $-1.73 \pm 0.57$ & $+3.02 \pm 0.70$ & $-0.31 \pm 1.59$ \\
\hline 5 & $-3.03 \pm 1.62$ & $-0.23 \pm 0.53$ & $-1.14 \pm 0.70$ & $-1.17 \pm 2.39$ & $-1.26 \pm 0.45$ & $-1.58 \pm 1.44$ & - & $-0.25 \pm 0.85$ & $+4.00 \pm 1.15$ & $-0.19 \pm 2.13$ \\
\hline 6 & $(-3.92 \pm 1.68)$ & - & $+0.68 \pm 1.22$ & $+0.37 \pm 1.53$ & $-1.10 \pm 1.80$ & $+2.28 \pm 0.81$ & - & - & - & $+0.56 \pm 1.39$ \\
\hline 7 & $(-2.92 \pm 1.04)$ & - & $-0.20 \pm 0.77$ & $+1.28 \pm 1.26$ & $-1.75 \pm 0.58$ & $+3.40 \pm 0.57$ & - & - & - & $+0.68 \pm 2.19$ \\
\hline 8 & - & - & $-0.83 \pm 1.20$ & $+0.72 \pm 0.80$ & $-1.09 \pm 0.55$ & $+0.46 \pm 1.14$ & - & - & - & $-0.19 \pm 0.91$ \\
\hline
\end{tabular}

* Values in parentheses are not included in mean because of short duration of study.

about an important change in the ratio of intracellular to plasma leucine enrichment.

Postabsorptive alanine fluxes are shown in Table V. Alanine fluxes were similar in both diet groups during the control periods

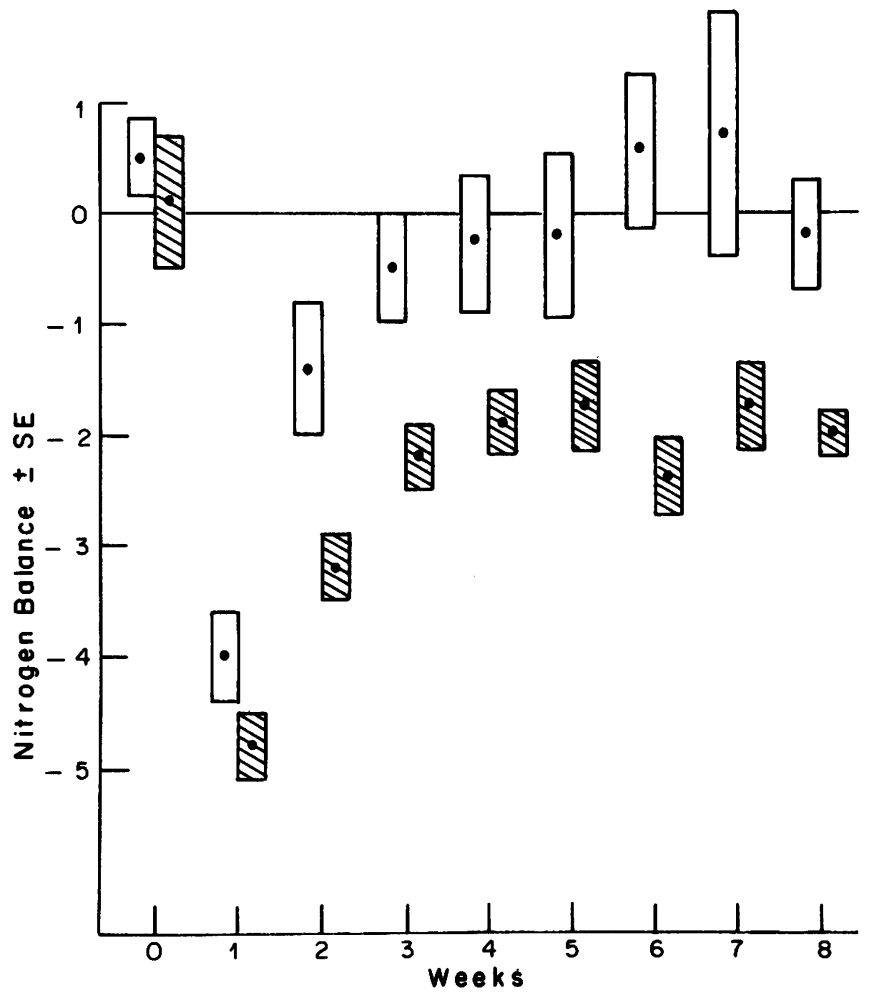

Figure 2. Average daily nitrogen balance $(\mathrm{g} / \mathrm{d})$ at different weeks for two weight reduction diets. Open bars indicate nitrogen balance for the 1.5 diet, shaded bars indicate nitrogen balance for the 0.8 diet. 15 subjects were included in the determination weeks $0-5 ; 8$ were included in the determination weeks 6-8. and after 3 and $8 \mathrm{wk}$, with decreases of 45 and $37 \%$ (1.5 and 0.8 diet). There was no correlation between alanine flux and leucine flux, leucine oxidation, or urinary nitrogen excretion.

\section{Discussion}

Despite considerable intersubject variability which is common with the technique (10), a different pattern of nitrogen balance is apparent for the two diets. Following an initial period of negativity, the balance approached zero for the 1.5 diet but rose only to $\sim-2 \mathrm{~g} / \mathrm{d}$ during the final 6 wk for the 0.8 diet with no trend towards further improvement. Average nitrogen balance on the control diet, which was adequate in energy, was not significantly different from zero for either diet.

If the nitrogen balance results are true, they imply signifcantly better protein retention with the higher protein diet. It has been stated that the nitrogen balance technique is subject to a systematic error, resulting in unrealistically positive nitrogen balances at high nitrogen intakes $(34,35)$. There are two reasons for arguing that the present results are not subject to this error. First, Oddoye and Margen (10) confirmed a continuous, positive nitrogen balance at very high protein intakes $(36 \mathrm{~g} \mathrm{~N} / \mathrm{d})$ in normal subjects studied for as long as $\mathbf{5 7} \mathrm{d}$. However, they also showed that with nitrogen intakes of $12 \mathrm{~g}$ (close to those taken in the present study), their subjects were essentially in nitrogen equilibrium. This contradicts the earlier criticism of the nitrogen balance technique at that nitrogen intake level (34). Secondly, internal data from the present study are in agreement with Oddoye and Margen (10). The average nitrogen balance for both diets was insignificantly different from zero on the control diet. If falsely positive nitrogen balances were recorded using nitrogen intakes at this level, they ought to have appeared on the control diet as well.

The present results differ from those of DeHaven et al. (5), who obtained an average nitrogen balance of $-1 \mathrm{~g} \mathrm{~N} / \mathrm{d}$ during the third week of a diet providing $100 \mathrm{~g}$ protein and $400 \mathrm{kcal}$. 


\begin{tabular}{|c|c|c|c|c|c|c|c|c|}
\hline \multicolumn{9}{|c|}{ 0.8 Diet } \\
\hline M.C. & P.D. & L.F. & L.J. & R.M. & S.S. & P.W. & S.W. & Mean $\pm S^{*}$ \\
\hline$+0.62 \pm 0.76$ & $-0.36 \pm 0.52$ & $+2.98 \pm 0.82$ & $-0.14 \pm 1.30$ & $+0.25 \pm 0.49$ & $+0.22 \pm 0.59$ & $(+0.19 \pm 0.77)$ & $-2.71 \pm 0.46$ & $+0.12 \pm 1.67$ \\
\hline$-4.29 \pm 0.96$ & $-5.94 \pm 1.52$ & $-5.26 \pm 1.20$ & $-4.42 \pm 1.60$ & $-3.49 \pm 0.75$ & $-4.76 \pm 0.93$ & $(-4.50 \pm 0.92)$ & $-5.41 \pm 1.65$ & $-4.80 \pm 0.82$ \\
\hline$-2.04 \pm 0.94$ & $-3.39 \pm 1.00$ & $-2.96 \pm 1.09$ & $-4.25 \pm 0.86$ & $-2.47 \pm 0.75$ & $-3.81 \pm 1.01$ & $(-2.68 \pm 0.66)$ & $-3.68 \pm 1.03$ & $-3.23 \pm 0.78$ \\
\hline$-1.30 \pm 0.48$ & $-3.11 \pm 1.14$ & $-1.39 \pm 0.45$ & $-2.88 \pm 0.63$ & $-2.57 \pm 0.56$ & $-1.48 \pm 1.68$ & $(-1.74 \pm 0.62)$ & $-2.14 \pm 0.41$ & $-2.17 \pm 0.71$ \\
\hline$-1.65 \pm 0.43$ & $-2.43 \pm 1.33$ & $-0.50 \pm 0.74$ & $-2.51 \pm 0.45$ & $-1.94 \pm 1.11$ & $-1.33 \pm 0.82$ & - & $-2.71 \pm 0.74$ & $-1.87 \pm 0.78$ \\
\hline$-1.49 \pm 1.65$ & $-2.44 \pm 0.32$ & $-2.94 \pm 2.07$ & $-2.65 \pm 1.05$ & $-0.98 \pm 0.62$ & $-0.25 \pm 1.22$ & - & $-1.43 \pm 0.43$ & $-1.74 \pm 0.98$ \\
\hline- & $-2.60 \pm 0.70$ & - & $-2.83 \pm 0.12$ & - & $-2.76 \pm 1.11$ & - & $-1.36 \pm 0.44$ & $-2.39 \pm 0.69$ \\
\hline- & $-2.31 \pm 0.51$ & - & $-2.46 \pm 0.79$ & - & $-1.05 \pm 0.57$ & - & $-1.19 \pm 0.46$ & $-1.75 \pm 0.74$ \\
\hline- & $-2.24 \pm 0.60$ & - & $-1.44 \pm 0.37$ & - & $-2.16 \pm 1.30$ & - & $-2.12 \pm 0.75$ & $-1.99 \pm 0.37$ \\
\hline
\end{tabular}

This was not significantly different from an average balance of -1.6 obtained in the same subjects while following a diet of 50 $\mathrm{g}$ protein and $50 \mathrm{~g}$ carbohydrate. The diets in that study were fat-free as compared with the present diets in which fat made up $\sim 36 \%$ of the calories. Sodium and potassium intakes were lower as well. Fat is not known to have an effect on protein

Table IV. Plasma Leucine Flux and Oxidation ( $\mu \mathrm{mol} / \mathrm{min}$ )

\begin{tabular}{|c|c|c|c|c|c|c|}
\hline \multirow[b]{2}{*}{ Subject } & \multicolumn{2}{|c|}{ Control period } & \multicolumn{2}{|c|}{3 wk } & \multicolumn{2}{|c|}{8 wk } \\
\hline & Flux & Oxidation & Flux & Oxidation & Flux & Oxidation \\
\hline \multicolumn{7}{|l|}{ 1.5 Diet } \\
\hline K.B. & 108.5 & 16.8 & 79.8 & 11.6 & - & - \\
\hline J.B. & 92.7 & 15.9 & 87.2 & 16.0 & - & - \\
\hline L.C. & 104.5 & 18.0 & 82.1 & 12.7 & 85.6 & 9.8 \\
\hline B.M. & 88.8 & 9.2 & 70.2 & 10.9 & - & - \\
\hline C.M. & 80.0 & 15.2 & 69.2 & 12.4 & 59.9 & 12.4 \\
\hline J.R. & 92.4 & 12.4 & 84.0 & 10.3 & - & - \\
\hline D.S. & 87.3 & 7.2 & 77.2 & 12.0 & - & - \\
\hline K.W. & 75.4 & 9.5 & 69.4 & 2.5 & - & \\
\hline Mean \pm SD & $91.2 \pm 11.1$ & $13.0 \pm 4.0$ & $77.4 \pm 7.1$ & $11.0 \pm 3.9$ & & \\
\hline Expressed per kilogram & $1.09 \pm 0.12$ & $0.16 \pm 0.04$ & $0.93 \pm 0.11$ & $0.13 \pm 0.05$ & & \\
\hline Expressed per kilogram IBW & $1.61 \pm 0.24$ & $0.23 \pm 0.07$ & $1.36 \pm 0.12$ & $0.19 \pm 0.07$ & & \\
\hline \multicolumn{7}{|l|}{ 0.8 Diet } \\
\hline M.C. & 88.8 & 9.4 & 67.2 & 5.0 & - & - \\
\hline P.D. & 90.0 & 17.0 & 69.1 & 10.1 & 66.9 & 7.2 \\
\hline L.F. & 106.7 & 8.3 & 81.9 & 7.5 & - & - \\
\hline L.J. & 93.1 & 10.1 & 85.4 & 9.0 & 82.7 & 11.3 \\
\hline R.M. & 91.9 & 11.2 & 84.1 & 11.1 & - & - \\
\hline S.S. & 96.2 & 9.7 & 76.5 & 6.0 & 74.0 & 11.5 \\
\hline P.W. & 105.1 & - & 77.1 & - & - & - \\
\hline S.W. & 96.3 & 16.5 & 75.5 & 8.8 & 71.2 & 12.8 \\
\hline Mean \pm SD & $96.0 \pm 6.7$ & $11.7 \pm 3.5$ & $77.1 \pm 6.6$ & $8.2 \pm 2.2$ & & \\
\hline Expressed per kilogram & $1.13 \pm 0.09$ & $0.14 \pm 0.05$ & $0.89 \pm 0.08$ & $0.09 \pm 0.03$ & & \\
\hline Expressed per kilogram IBW & $1.76 \pm 0.14$ & $0.22 \pm 0.07$ & $1.42 \pm 0.13$ & $0.15 \pm 0.04$ & & \\
\hline
\end{tabular}

Values expressed as mean \pm SD. 


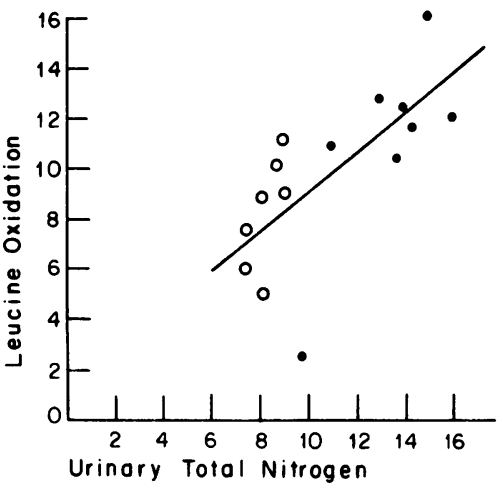

Figure 3. Fasting leucine oxidation rate $(\mu \mathrm{mol} / \mathrm{min})$ compared with average daily urinary nitrogen excretion $(\mathrm{g} / \mathrm{d})$ during the third week of dieting. Closed circles indicate values for the 1.5 diet; open circles for the 0.8 diet. $r=0.70, \mathrm{y}=0.95 \pm 0.78 \times . P<0.01$.

retention in the very low calorie range (36); therefore, the difference in fat contents in the diets of the different studies is probably not important. However, the potential attainment of nitrogen equilibrium during the high protein period might have been prevented in the study of DeHaven et al. (5) if there was coexistent mild potassium deficiency $(37,38)$.

Other investigators have reported negative nitrogen balance in obese individuals on very low calorie diets providing protein at levels even higher than in the present study $(39,40)$. However, this has been more commonly observed in men and not in women, as were included in the present study. The effect of initial body weight is also to be considered when comparing nitrogen balance studies in the obese. Severely overweight patients, perhaps with increased lean body mass, might be in more negative nitrogen balance than only moderately obese ones at a given protein intake. These considerations, when taken with the individual variability shown among the subjects in Table III, indicate that it is not possible to confidently predict the nitrogen balance of individual obese subjects on very low calorie diets. Nevertheless, our results do indicate that nitrogen balance is likely to be more favourable at higher protein intakes.

In contrast to the important differences between the diets with regard to nitrogen balance, there were equivalent decreases in postabsorptive plasma leucine flux. The $\sim 20 \%$ decrease observed with both diets indicates only a mild effect on body protein metabolism when compared with prolonged fasting, during which decreases of $65 \%$ in leucine appearance have been inferred (16). It is noteworthy that leucine flux diminished equivalently for both diets even though the 1.5 diet involved a decrease in energy only from the control diet, while the 0.8 diet involved a decrease in both protein and energy. A simple decrease in the protein intake (at maintenance energy) is associated with a decrease in postabsorptive leucine flux (13); therefore, it might have been predicted that the 0.8 diet would be associated with a greater decrease in leucine flux than the 1.5 diet. This was not observed. Perhaps no greater decrease occurred with the
0.8 diet because its protein level is known to be adequate for nitrogen equilibrium when the energy intake is ample.

The better nitrogen balance with the 1.5 diet should be indicated in terms of the kinetic model by a more favourable balance between protein intake and protein oxidized. The failure of subjects on the 0.8 diet to establish nitrogen equilibrium evidently represents a failure of the body to decrease the rate of destruction of amino acids to the same extent that amino acid intake was decreased in going from the control diet (1.5 $\mathrm{g} / \mathrm{kg} \mathrm{IBW})$ to the experimental diet $(0.8 \mathrm{~g} / \mathrm{kg} \mathrm{IBW})$. The relationship in Fig. 3 may be used to illustrate this. From nitrogen intake and fecal nitrogen, it may be calculated that the urinary nitrogen excretion compatible with nitrogen equilibrium would have been $6.0 \mathrm{~g} / \mathrm{d}$ for the $0.8 \mathrm{diet}$. This corresponds (Fig. 3) to a postabsorptive leucine oxidation rate of $5.6 \mu \mathrm{mol} / \mathrm{min}$. The observed rate, $8.2 \mu \mathrm{mol} / \mathrm{min}$, is significantly higher $(P<0.05)$, indicating that while leucine oxidation did decrease as anticipated with the 0.8 diet, it was not by enough to permit the reestab-

Table V. Plasma Alanine Flux Measured with $L-\left[{ }^{I 5} N\right]$ alanine ( $\mu \mathrm{mol} / \mathrm{min})$

\begin{tabular}{llll}
\hline Subject & $\begin{array}{l}\text { Control } \\
\text { period }\end{array}$ & $3 \mathbf{w k}$ & 8 wk \\
\hline 1.5 Diet & & & \\
K.B. & 343 & 181 & - \\
J.B. & - & - & - \\
L.C. & 291 & 156 & 110 \\
B.M. & 199 & 117 & 105 \\
C.M. & 187 & 129 & 114 \\
J.R. & 190 & 114 & - \\
D.S. & 317 & 127 & - \\
K.W. & 195 & 123 & - \\
Mean \pm SD & & & \\
Expressed per kilogram & $246 \pm 68$ & $135 \pm 24$ & \\
Expressed per kilogram IBW & $4.34 \pm 1.11$ & $2.41 \pm 0.49$ & \\
& & &
\end{tabular}

0.8 Diet

$\begin{array}{llll}\text { M.C. } & 231 & 178 & - \\ \text { P.D. } & - & - & - \\ \text { L.F. } & 311 & 163 & - \\ \text { L.J. } & 242 & 162 & 184 \\ \text { R.M. } & - & - & - \\ \text { S.S. } & 251 & 212 & 166 \\ \text { P.W. } & - & - & - \\ \text { S.W. } & 289 & 146 & 131 \\ \text { Mean } \pm \text { SD } & 265 \pm 34 & 166 \pm 31 & \\ \text { Expressed per kilogram } & 2.94 \pm 0.37 & 1.95 \pm 0.52 & \\ \text { Expressed per kilogram IBW } & 4.88 \pm 0.70 & 3.17 \pm 0.52 & \end{array}$

Values expressed as mean $\pm \mathrm{SD}$. 
lishment of nitrogen equilibrium. The comparable theoretical oxidation rate for the $1.5 \mathrm{diet}$ is $10.8 \mu \mathrm{mol} / \mathrm{min}$, which is indistinguishable from the observed value $(11.0 \mu \mathrm{mol} / \mathrm{min})$ and reasonable as the group on the 1.5 diet was close to nitrogen equilibrium by that time. Thus, for the 1.5 diet, no reduction in amino acid oxidation was necessary to establish nitrogen balance because the protein intake was so generous that it permitted nitrogen equilibrium even in the presence of the inefficient amino acid utilization caused by the energy deficit.

It is emphasized that postabsorptive plasma leucine flux and oxidation do not fully characterize the response to the very low calorie diets studied because they do not describe the metabolic events surrounding actual meal ingestion. Leucine flux and oxidation are known to increase during the ingestion of meals including protein compared with intermeal values in normal subjects (41). This is likely to be true of very low calorie diets as well, as the diurnal pattern of urea excretion is preserved (unpublished observation). Therefore, the similar leucine kinetics with both diets in the postabsorptive state do not rule out important fed state differences. It remains to be determined how fed-state flux and oxidation rates would be maintained with isonitrogenous diets at maintenance and very low energy intakes. From the present nitrogen balance results, it may be predicted that a pattern similar to but quantitatively more important than that in the postabsorptive state would be obtained, namely rates of leucine oxidation inappropriately high in relation to intake with the 0.8 diet.

The effect of both diets was a decrease in postabsorptive alanine flux more than twice that in the leucine flux, though still not as dramatic as the $65 \%$ decrease reported during prolonged fasting (18). Alanine flux is a function of protein turnover, of the carbohydrate supply (42), and of the state of nitrogen availability in skeletal muscle (21). A decrease in alanine flux as dramatic as in prolonged fasting would not be anticipated in this setting, because the leucine results indicate that alanine appearance due to protein turnover would be only mildly af fected. However, the disproportionate decrease in alanine flux compared with leucine flux suggests that de novo alanine synthesis in the periphery diminished with both diets. Plasma glucose turnover decreases only marginally with very low calorie diets of the type studied here (L. J. Hoffer, R. W. Wannemacher, V. R. Young, and B. R. Bistrian, unpublished observations), so the large decrease in alanine flux was likely due to decreased peripheral nitrogen availability, as occurs in prolonged fasting (17). Supporting this notion, urinary 3-methylhistidine excretion, an indicator of the rate of skeletal muscle protein breakdown (43), has been observed to decrease by a similar extent during very low calorie dieting and during prolonged fasting $(15,44$, 45; L. J. Hoffer, R. W. Wannemacher, V. R. Young, and B. R. Bistrian, unpublished observations). When taken together with the leucine results, this suggests that although protein turnover in the body as a whole is relatively well maintained with very low calorie diets, skeletal protein turnover may be markedly affected. The peripheral tissues are a major source of whole body alanine flux (17), but the rate of skeletal muscle protein turnover is usually estimated to account for only $25 \%$ of the total in the body $(9,46)$. Thus, even a marked change in peripheral protein metabolism would not be well reflected in measures of whole body amino acid turnover.

In summary, nitrogen balance was superior with a very low calorie diet which provided a protein intake substantially greater than the RDA, and on the average, nitrogen balance approached equilibrium in moderately obese young women. A protein intake at only the RDA level was incompatible with nitrogen equilibrium, being associated with continuing nitrogen losses of $2 \mathrm{~g} /$ d. Despite the differences in nitrogen balance, basal whole body protein turnover (inferred in the postabsorptive state from plasma leucine flux) was well maintained after $8 \mathrm{wk}$ of continuous dieting, declining by only $20 \%$ when compared with control values. However, this preservation of body protein turnover rates may have been restricted to the visceral compartment, because plasma alanine flux decreased in a manner suggesting diminished nitrogen availability in the periphery similar to prolonged fasting.

\section{Acknowledgments}

The insulin determinations were done by R. W. Wannemacher, Fort Detrick, MD.

This research was supported in part by grants AM 26349 and AM 15856 from the National Institute of Arthritis, Metabolism, and Digestive Diseases, and by grant RR- 88 from the General Clinical Research Centers.

\section{References}

1. Talbot, J. 1979. Research needs in management of obesity by severe calorie restriction. Bureau of Foods, Food and Drug Administration, Department of Health, Education and Welfare. Life Science Research Office, Federation of American Societies for Experimental Biology, Bethesda, MD.

2. Sours, H. E., V. P. Frattali, C. D. Brand, R. A. Feldman, A. L. Forbes, R. D. Swanson, and A. L. Paris. 1981. Sudden death associated with very low calorie weight reduction regimens. Am. J. Clin. Nutr. 34:453-461.

3. Committee on Dietary Allowances, Food and Nutrition Board. 1980. Recommended Dietary Allowances. National Academy of Sciences. Washington, DC.

4. Calloway, D. H. 1975. Nitrogen balance of men with marginal intakes of protein and energy. J. Nutr. 105:914-923.

5. DeHaven, J., R. Sherwin, R. Hendler, and P. Felig. 1980. Nitrogen and sodium balance and sympathetic-nervous system activity in obese subjects treated with a low-calorie protein or mixed diet. N. Engl. J. Med. 302:477-482.

6. Howard, A. N., A. Grant, O. Edwards, E. R. Littlewood, and I. M. Baird. 1978. The treatment of obesity with a very low calorie liquid-formula diet: an inpatient/outpatient comparison using skimmedmilk protein as the chief protein source. Int. J. Obesity. 2:321-332.

7. Bistrian, B. R., J. Winterer, G. L. Blackburn, V. Young, and M. Sherman. 1977. Effect of a protein-sparing diet and brief fast on nitrogen metabolism in mildly obese subjects. J. Lab. Clin. Med. 89:1030-1035.

8. Bistrian, B. R., M. Sherman, and V. R. Young. 1981. The mechanism of nitrogen sparing in fasting supplemented by protein and carbohydrate. J. Clin. Endocrinol. Metab. 53:874-878. 
9. Munro, H. N., and M. C. Crim. 1980. Protein and amino acids. In Modern Nutrition in Health and Disease. R. S. Goodhart and M. E. Shils, editors. Lea and Febiger, Philadelphia. 51-98.

10. Oddoye, E. A., and S. Margen. 1979. Nitrogen balance studies in humans: long-term effect of high nitrogen intake on nitrogen accretion. J. Nutr. 109:363-377.

11. Waterlow, J. C., P. J. Garlick, and D. J. Millward. 1978. Protein Turnover in Mammalian Tissues and in the Whole Body. North-Holland Publishing Co., Amsterdam.

12. Golden, M. H. N., J. C. Waterlow, and D. Picou. 1977. Protein turnover, synthesis and breakdown before and after recovery from protein-energy malnutrition. Clin. Sci. Mol. Med. 53:473-477.

13. Motil, K. J., D. E. Matthews, D. M. Bier, J. F. Burke, H. N. Munro, and V. R. Young. 1981. Whole-body leucine and lysine metabolism: response to dietary protein intake in young men. Am. J. Physiol. 240:E712-E721.

14. Felig, P., T. Pozefsky, and E. Marliss. 1970. Alanine: key role in gluconeogenesis. Science (Wash. DC). 167:1003-1004.

15. Winterer, J., B. R. Bistrian, C. Bilmazes, G. L. Blackburn, and V. R. Young. 1980. Whole body protein turnover studied with ${ }^{15} \mathrm{~N}-$ glycine and muscle protein breakdown in mildly obese subjects during a protein-sparing diet and a brief total fast. Metab. Clin. Exp. 29:575581 .

16. Sherwin, R. S. 1978. Effect of starvation on the turnover and metabolic response to leucine. J. Clin. Invest. 61:1471-1481.

17. Felig, P. 1973. The glucose-alanine cycle. Metab. Clin. Exp. 22:179-207.

18. Marliss, E. B., T. T. Aoki, A. F. Morgan, R. C. O'Connell, and G. F. Cahill, Jr. 1970. Alanine in catabolic states. Clin. Res. 18:539.

19. Allison, J. B., and J. W. C. Baird. 1964. Elimination of nitrogen from the body. In Mammalian Protein Metabolism. H. N. Munro and J. B. Allison, editors. Academic Press, Inc., New York. 1:483-512.

20. Matthews, D. E., K. J. Motil, D. K. Rohrbaugh, J. F. Burke, V. R. Young, and D. M. Bier. 1980. Measurement of leucine metabolism in man from a primed, continuous infusion of $\mathrm{L}-\left[1-{ }^{13} \mathrm{C}\right]$ leucine. Am. J. Physiol. 238:E473-E479.

21. Ben Galim, E., K. Hruska, D. M. Bier, D. E. Matthews, and M. W. Haymond. 1980. Branched-chain amino acid nitrogen transfer to alanine in vivo in dogs. J. Clin. Invest. 66:1295-1304.

22. Fogarty International Center Series on Preventive Medicine. In Obesity in Perspective. G. A. Bray, editor. Department of Health, Education and Welfare Publication No. (National Institutes of Health) 75708. U. S. Department of Health, Education and Welfare, Washington, DC. $2: 72$.

23. Munro, H. N., and A. Fleck. 1969. Analysis of tissues and body fluids for nitrogenous constituents. In Mammalian Protein Metabolism. H. N. Munro, editor. Academic Press, Inc., New York. 3:424-525.

24. Joint FAO/World Health Organization Expert Committee. 1973. Energy and Protein Requirements. Geneva: World Health Organization. (WHO Technical Report Series No. 522).

25. Abumrad, N. N., D. Rabin, M. P. Diamond, and W. W. Lacy. 1981. Use of a heated superficial hand vein as an alternative site for the measurement of amino acid concentrations and for the study of glucose and alanine kinetics in man. Metab. Clin. Exp. 30:936-940.

26. Allsop, J. R., R. R. Wolfe, and J. F. Burke. 1978. Tracer priming the bicarbonate pool. J. Appl. Physiol. 45:137-139.
27. Bergmeyer, H. U. 1971. Methods of Enzymatic Analysis. Academic Press, Inc., New York.

28. Ho, R. J. 1970. Radiochemical assay for long-chain fatty acids using ${ }^{63} \mathrm{Ni}$ as tracer. Anal. Biochem. 36:105-113.

29. Juan, C., and T. W. AvRuskin. 1971. A combined immunoassay of human growth hormone and insulin. Cumulative assessment of assay performance. J. Clin. Endocrinol. Metab. 33:150-152.

30. Matthews, D. E., E. Ben-Galim, and D. M. Bier. 1979. Determination of stable isotope enrichment in individual plasma amino acids by chemical ionization mass spectrometry. Anal. Chem. 51:80-84.

31. Matthews, D. E., H. P. Schwarz, R. D. Yang, K. J. Motil, V. R. Young, and D. M. Bier. 1982. Relationship of plasma leucine and ketoisocaproate during a $\mathrm{L}-\left[1-{ }^{13} \mathrm{C}\right]$ leucine infusion in man: a method for measuring human intracellular leucine tracer enrichment. Metab. Clin. Exp. 31:1105-1112.

32. Issekutz, B., Jr., P. Paul, H. I. Miller, and W. M. Bortz. 1968. Oxidation of FFA in lean and obese humans. Metab. Clin. Exp. 17:6273.

33. Reichard, G. A., O. E. Owen, A. C. Haff, P. Paul, and W. M. Bortz. 1974. Ketone-body production and oxidation in fasting obese humans. J. Clin. Invest. 53:508-515.

34. Hegsted, D. M. 1976. Balance studies. J. Nutr. 106:307-311.

35. Hegsted, D. M. 1978. Assessment of nitrogen requirements. Am. J. Clin. Nutr. 31:1669-1677.

36. Munro, H. N. 1951. Carbohydrate and fat as factors in protein utilization and metabolism. Physiol. Rev. 31:449-488.

37. Phinney, S. D. 1980. Low calorie versus mixed diet. N. Engl. J. Med. 303:158-159.

38. Sherwin, R. S., R. Hendler, J. DeHaven, and P. Felig. Low calorie versus mixed diet. N. Engl. J. Med. 303:159.

39. Yang, M.-U., J. L. Barbosa-Saldivar, F. X. Pi-Sunyer, and T. B. Van Itallie. 1981. Metabolic effects of substituting carbohydrate for protein in a low-calorie diet: a prolonged study in obese patients. Int. J. Obesity. 5:231-236.

40. Fisler, J. S., E. J. Drenick, D. E. Blumfield, and M. E. Swendseid. 1982. Nitrogen economy during very low calorie reducing diets: quality and quantity of dietary protein. Am. J. Clin. Nutr. 35:471-486.

41. Garlick, P. J., G. A. Clugston, R. W. Swick, and J. C. Waterlow. 1980. Diurnal pattern of protein and energy metabolism in man. $A m$. J. Clin. Nutr. 33:1983-1986.

42. Young, V. R. 1981. Protein metabolism and nutritional state in man. Proc. Nutr. Soc. 40:343-359.

43. Young, V. R., and H. N. Munro. 1978. N'-methylhistidine (3methylhistidine) and muscle protein turnover: an overview. Fed. Proc. 37:2291-2300.

44. Marliss, E. B., F. T. Murray, and A. F. Nakhooda. 1978. The metabolic response to hypocaloric diets in obese man. J. Clin. Invest. 62:468-479.

45. Young, V. R., L. N. Haverberg, C. B. Bilmazes, and H. N. Munro. 1973. Potential use of 3-methylhistidine excretion as an index of progressive reduction in muscle protein catabolism during starvation. Metab. Clin. Exp. 22:1429-1435.

46. Wannemacher, R. W. 1975. Protein metabolism. In Total Parenteral Nutrition. H. Ghadimi, editor. John Wiley \& Sons, New York. $85-154$. 